\title{
Pengaruh perilaku ibu terhadap keikutsertaan program KB di kota medan tahun 2019
}

\author{
Nopita Yanti Sitorus ${ }^{1 *}$, Maimunah $\mathbf{R}^{2}$ \\ 1,2Program Studi D-III Kebidanan STIKes Flora, Medan.`Email : nopistr27@gmail.com
}

\begin{abstract}
Factors affecting participation of the family planning program in Medan, Indonesia
\end{abstract}

Background: Family Planning is one of the most effective ways to increase family endurance and mother, children and women safety. In fact, there are many mothers who do not use contraception so as they have many children. Therefore, the distance between child births is very close.

Purpose: Knowing of the effects of mothers' behavior, attitude, and knowledge on their participation of the Family planning program in Medan in 2019.

Method: A quantitative analytical method by cross sectional research design and conducted in 13 Public Health Centers (Puskesmas) and Maternity Clinics in Medan, North Sumatra Provinc, Indonesia. The population were 745 mothers of childbearing age and the samples were 260 mothers. The primary and secondary data were collected. They were analyzed by univariat and bivariate data analysis by using chi-square test with the level of confidence $95 \%$.

Results: The findings showed that mothers' knowledge affect their participation in family planning program with $p=0,005<0,05$. Mothers' attitude affects their participation in the program with $p=0,009<0,05$. And mothers' behavior affects their participation in the program with $p=0,000<0,05$

Conclusion: This study proves that mothers' participation in the family planning program in Medan is affected by knowledge, attitude, and behavior.

Suggestion: The provincial health services authority to be cooperate with Board of Family Planning Program in Medan in order to perform health promotions of Family Planning in terms of the use of appropriate contraceptive and prevention of early marriage. Health promotions by using counseling and health education are expected to improve mothers' knowledge, to change their negative attitude, and to improve their behavior.

\section{Keywords: Behavior; Attitude; Knowlegde; Participation; Family Planning Program}

Pendahuluan: Keluarga Berencana merupakan salah satu cara yang paling efektif untuk meningkatkan ketahanan keluarga, kesehatan, dan keselamatan ibu, anak, serta perempuan. Tetapi faktanya masih banyak ibu yang tidak menggunakan alat kontrasepsi sehingga memiliki banyak anak, dan jarak kelahiran yang dekat.

Tujuan: Mengetahui faktor-faktor ibu terhadap keikutsertaan program Keluarga Berencana (KB).

Metode: Penelitian kuantitatif dengan metode analitik menggunakan rancangan cross sectional, dilakukan di beberapa puskesmas dan rumah bersalin di kota Medan. Populasinya ibu pasangan usia subur sebanyak 745 orang dan sampel diperoleh sebanyak 260 orang. Data yang digunakan adalah data primer dan sekunder dan dianalisa secara univariat dan bivariat dengan menggunakan uji chi-square dengan tingkat kepercayaan $95 \%$

Hasil: Menunjukkan bahwa pengetahuan ibu berpengaruh terhadap keikutsertaan program $K B, p=0,005<0,05$. Sikap ibu berpengaruh terhadap keikutsertaan program $K B, p=0,009<0,05$ dan perilaku ibu berpengaruh terhadap keikutsertaan program KB, $\mathrm{p}=0,000<0,05$.

Simpulan: Penelitian ini membuktikan bahwa keikutsertaan ibu dalam program KB di Kota Medan dipengaruhi pengetahuan, sikap, dan perilaku.

Saran: Dinas Kesehatan Kota Medan supaya dapat bekerjasama dengan BKKBN Kota Medan melakukan promosi kesehatan tentang Keluarga Berencana, penggunaan alat kontrasepsi yang sesuai, pencegahan pernikahan usia dini. Promosi kesehatan dengan penyuluhan atau pendidikan kesehatan diharapkan dapat meningkatkan pengetahuan, merubah sikap yang negatif menjadi positif, dan meningkatkan tindakan menjadi lebih baik.

Kata Kunci: Pengetahuan; Sikap; Perilaku; Keikutsertaan; Program KB 
Pengaruh perilaku ibu terhadap keikutsertaan program KB di kota medan tahun 2019

\section{PENDAHULUAN}

Tingginya angka kelahiran di Indonesia masih menjadi masalah utama dalam kependudukan. Sejak tahun 2004, program Keluarga Berencana (KB) dinilai berjalan lambat, hingga angka kelahiran mencapai 4,5 juta pertahun dan pada tahun 2010 berdasarkan sensus penduduk mencapai 237 juta jiwa. Ledakan penduduk disadari akan berpengaruh pada ketersediaan pangan dan kualitas sumber daya manusia. Untuk menghindari dampak tersebut, pemerintah berusaha keras menekan angka kelahiran hingga dibawah 237 juta jiwa pertahun. (Affandi, 2014; Suratun, Heryani, \& Manurung, 2015; Saifuddin, 2006).

Berdasarkan data dari Badan Koordinasi Keluarga Berencana (BKKBN) Sumatera Utara peserta baru pada tahun 2008 mencapai 108.014 peserta atau $66,11 \%$. Dari pencapaian sebanyak 108.014 peserta KB baru tersebut yaitu Intra Uterine Device (IUD) mencapai 10.773 peserta $(5,98 \%)$, Metode Operasi Pria (MOP) mencapai 351 peserta $(0,19 \%)$, MOW mencapai 4.560 peserta $(2,53 \%)$, kondom mencapai 13.545 peserta $(7.52 \%)$, implant mncapai 120.109 peserta $(40,05 \%)$ dan pil mencapai 66.586 peserta $(36,99 \%)$. Data SUSENAS (Survey Sosial Ekonomi Nasional) tahun 2015 menunjukkan persentase PUS (Pasangan Usia Subur) yang sedang menggunakan alat/cara KB sebesar 59,98 persen, pernah menggunakan tetapi sekarang tidak menggunakan sebesar 12,64\%, dan PUS yang tidak menggunakan KB sebesar 27,38\%. Berdasarkan tipe daerah, PUS di perdesaan yang menggunakan alat/cara KB untuk menunda/mencegah kehamilan relative lebih tinggi dibandingkan dengan di perkotaan $(61,92 \%$ berbanding 57,98 \%) (Badan Kependudukan dan Keluarga Berencana Nasional. 2010)

Jumlah Pasangan Usia Subur tahun 2012 di Sumatera Utara adalah 2.317.450. Dengan akseptor Intra Uterine Device (IUD) 140.480 $(10,74 \%)$, Pil 425.630 (32,54 \%), Kondom 83.450 $(6,38 \%)$, Suntik 422.310 (32,30\%), Implant $121.670(9.30 \%)$, MOP (Metode Operasi Pria) $4.730(0,36 \%)$ dan MOW (Metode Operasi Wanita) 109.590 (8,38 \%) ( Dinas Kesehatan Provinsi Sumatera Utara, 2015).
Program Keluarga Berencana (KB) merupakan salah satu program pemerintah Indonesia untuk menanggulangi masalah pertumbuhan penduduk. Gerakan KB Nasional adalah gerakan masyarakat yang menghimpun dan mengajak segenap potensi masyarakat untuk berpertisipasi aktif dalam melambangkan dan membudayakan NKKBS dalam rangka meningkatkan mutu sumber daya Indonesia. Hasil sensus penduduk 2004 oleh BPS menunjukan bahwa gerakan KB Nasional telah berhasil merampungkan landasan pembentukan keluarga kecil, dalam rangka pelembagaan Norma Keluarga Kecil Bahagia Sejahtera (NKKBS) langkah besar yang perlu dibangun selanjutnya adalah pembangunan keluarga kecil sejahtera (Prawiroharjo, 2008; Kusumawati, Purwanti,\& Kusuma, 2016).

Hasil survey awal yang dilakukan peneliti didapat data akseptor yang memakai implant $5 \mathrm{ibu}$, alasannya takut tidak bisa melakukan kerja berat. Pemakai AKDR 3 ibu, alasannya biayanya cukup mahal sehingga sedikit yang memakainya. Pemakai suntik 56 ibu, alasannya lebih praktis dan terjangkau. Dan pemakai pil 20 ibu, alasannya kontrasepsi pil akan menjadi rutinitas, sehingga terkadang sebagian orang lupa meminumnya.

\section{METODE PENELITIAN}

Penelitian analitik dengan jenis penelitian kuantitatif yang bertujuan untuk melihat bagaimana pengaruh perilaku ibu terhadap keikutsertaan program KB. Penelitian ini dilaksanakan pada bulan Maret hingga Agustus 2019, mendapatkan surat layak etiknya nomor: 440/226.05/UI/2019 dari Fakultas Kedokteran Universitas Sumatera Utara.

Populasinya ibu pasangan usia subur yang ada di Kota Medan yang tersebar di 13 wilayah penelitian yang berjumlah 745 orang. Sampelnya menggunakan Stratified Random Sampling yang berjumlah 260 orang yang tersebar di 13 lokasi penelitian yaitu : Puskesmas Desa Lalang, Puskesmas Sunggal, Puskesmas Darussalam, RB Hadijah, RB Suryani, RB Sumi Ariani, Klinik Ananda, Klinik Bromo, RB Sumi Ariani, RB Hanum Husada, RB Sari, Klinik Eka Sri Wahyuni, Klinik Hamidah, dan seluruh Puskesmas dan Klinik/RB terdapat di Kota Medan.

Pengumpulan data menggunakan kuesioner yang terdiri dari data karakteristik ibu yang terdiri dari: usia, pendidikan, pekerjaan dan paritas. Selain itu juga terdapat kuesioner pengetahuan, 
Pengaruh perilaku ibu terhadap keikutsertaan program KB di kota medan tahun 2019

sikap dan perilaku ibu terhadap program KB yang masing - masing variable terdiri dari 10 item pertanyaan. Teknik analisa data menggunakan analisa data univariat dan bivariat untuk melihat pengetahuan, sikap dan perilaku ibu dengan menampilkan frekuensi dan persentase.

Tabel 1. Aspek Pengukuran

\begin{tabular}{|c|c|c|c|}
\hline Variabel & Kategori & Skala & Alat ukur \\
\hline Pendidikan & $\begin{array}{l}\text { SD } \\
\text { SMP } \\
\text { SMA } \\
\text { Diploma/PT }\end{array}$ & Ordinal & Kuesioner \\
\hline Pekerjaan & $\begin{array}{l}\text { IRT } \\
\text { Pegawai Swasta } \\
\text { Wiraswasta } \\
\text { PNS }\end{array}$ & Ordinal & Kuesioner \\
\hline Umur & $\begin{array}{l}<20 \text { tahun } \\
20-30 \text { tahun } \\
>30 \text { tahun }\end{array}$ & Ordinal & Kuesioner \\
\hline Paritas & $\begin{array}{l}\text { Paritas } 1 \\
\text { Paritas } 2 \\
\text { Paritas } 3 \\
\text { Paritas } 4\end{array}$ & Ordinal & Kuesioner \\
\hline Pengetahuann & $\begin{array}{l}\text { Baik (8-10) } \\
\text { Sedang (5-7) } \\
\text { Kurang (0-4) }\end{array}$ & Ordinal & Kuesioner \\
\hline Sikap & $\begin{array}{l}\text { Positif (21-30) } \\
\text { Negatif (10-20) }\end{array}$ & Ordinal & Kuesioner \\
\hline Perilaku & $\begin{array}{l}\text { Baik }(13-15) \\
\text { Sedang }(9-12) \\
\text { Kurang }(5-8)\end{array}$ & Ordinal & Kuesioner \\
\hline
\end{tabular}


HASIL

Tabel 2. Distribusi Frekuensi Berdasarkan Karakteristik Responden N=260

\begin{tabular}{lcc}
\hline Variabel & Frekuensi (f) & Persentase (\%) \\
\hline Usia & & \\
$<20$ tahun & 4 & 1,5 \\
20-35 tahun & 207 & 79,6 \\
$>35$ tahun & 49 & 18,9 \\
Pendidikan & & \\
SMP & 34 & 13,1 \\
SMA & 175 & 67,3 \\
Diploma/ PT & 51 & 19,6 \\
Pekerjaan & & \\
IRT & 86 & 33,1 \\
Pegawai Swasta & 133 & 51,1 \\
Wiraswasta & 15 & 5,8 \\
PNS & 17 & 6,5 \\
Karyawan/Buruh & 9 & 3,5 \\
Partitas & & \\
Paritas 1 & 51 & 19,6 \\
Paritas 2 & 132 & 50,8 \\
Paritas 3 & 59 & 22,7 \\
Paritas 4 & 18 & 6,9 \\
\hline
\end{tabular}

Tabel diatas menunjukkan bahwa dari 260 responden yang diteliti sebagian besar berumur 20-35 tahun sebanyak 207 orang $(79,6 \%)$, sebagian kecil berumur $<20$ tahun sebanyak 4 orang $(1,4 \%)$, sebagian besar responden berpendidikan SMA sebanyak 175 orang $(67,3 \%)$, sebagian kecil responden berpendidikan SMP sebanyak 34 orang $(13,1 \%)$, sebagian besar responden bekerja sebagai pegawai swasta sebanyak 133 orang $(51,1 \%)$, sebagian kecil responden bekerja sebagai karyawan/buruh sebanyak 9 orang $(3,5 \%)$, sebagian besar responden paritas 2 sebanyak 132 orang (50,8\%), sebagian kecil paritas 4 sebanyak 18 orang $(6,9 \%)$.

Tabel 3. Distribusi Frekuensi Responden berdasarkan Keikutsertaan dan Jenis Kontrasepsi yang digunakan $\mathrm{N}=260$

\begin{tabular}{lcc}
\hline Variabel & Frekuensi (f) & Persentase (\%) \\
& & \\
\hline Keikutsertaan KB & 218 & 83,8 \\
lkut & 42 & 16,2 \\
Tidak ikut & & \\
Jenis Kontrasepsi & 94 & 36,2 \\
IUD/AKDR & 68 & 26,2 \\
KB Suntik & 38 & 14,6 \\
Pil KB & 3 & 1,2 \\
Implan/Susuk KB & 9 & 3,5 \\
Sterilisasi & 5 & 1,9 \\
Kondom & 1 & 0,4 \\
Senggama terputus & 42 & 16,2 \\
Tidak menggunakan & & \\
\hline
\end{tabular}

Tabel diatas menunjukkan sebagian besar responden ikut program KB sebanyak 218 orang $(83,8 \%)$, sebagian kecil responden tidak ikut program KB sebanyak 42 orang $(16,2 \%)$, sebagian besar responden 
Pengaruh perilaku ibu terhadap keikutsertaan program KB di kota medan tahun 2019

menggunakan kontrasepsi IUD/AKDR sebanyak 94 orang $(36,2 \%)$ dan responden yang tidak menggunakan alat kontrasepsi sebanyak 42 orang $(16,2 \%)$.

Tabel 4. Faktor-Faktor Yang Mempengaruhi Keikutsertaan Program KB

\begin{tabular}{|c|c|c|c|c|c|c|c|}
\hline \multirow{3}{*}{ Variabel } & \multicolumn{4}{|c|}{ Keikutsertaan Program KB } & \multirow{2}{*}{\multicolumn{2}{|c|}{ Total }} & \multirow{3}{*}{$p$-value } \\
\hline & \multicolumn{2}{|c|}{ lkut } & \multicolumn{2}{|c|}{ Tidak lkut } & & & \\
\hline & $n$ & $(\%)$ & $\mathrm{n}$ & (\%) & $\mathbf{N}$ & $(\%)$ & \\
\hline \multicolumn{8}{|c|}{ Pengetahuan } \\
\hline Baik & 93 & 35,8 & 14 & 5,4 & 107 & 41,2 & \multirow{3}{*}{0,005} \\
\hline Sedang & 93 & 35,8 & 13 & 5,0 & 106 & 40,8 & \\
\hline Kurang & 32 & 12,2 & 15 & 5,8 & 47 & 18,0 & \\
\hline \multicolumn{8}{|l|}{ Sikap } \\
\hline Positif & 138 & 53,1 & 17 & 6,5 & 155 & 59,6 & \multirow{3}{*}{0,009} \\
\hline Negatif & 80 & 30,8 & 25 & 9,6 & 105 & 40,4 & \\
\hline \multicolumn{7}{|l|}{ Perilaku } & \\
\hline Baik & 63 & 24,2 & 4 & 1,5 & 67 & 25,8 & \multirow{3}{*}{0,000} \\
\hline Sedang & 150 & 57,7 & 14 & 5,4 & 164 & 63,1 & \\
\hline Kurang & 5 & 1,9 & 24 & 9,2 & 29 & 11,1 & \\
\hline
\end{tabular}

Tabel di atas menunjukkan bahwa dari 107 responden yang berpengetahuan baik mayoritas ikut program KB sebanyak 93 orang $(35,8 \%)$. Dari 106 responden yang berpengetahuan sedang mayoritas ikut program KB sebanyak 93 orang $(35,8 \%)$. Dari 47 responden yang berpengetahuan kurang mayoritas ikut program KB sebanyak 32 orang (12,2\%). Responden yang tidak menggunakan alat kontrasepsi lebih banyak pada responden yang berpengetahuan kurang sebanyak 15 orang $(5,8 \%)$. Hasil uji statistik dengan menggunakan uji chi-square diperoleh $p$-value sebesar 0,005 artinya terdapat pengaruh antara pengetahuan terhadap keikutsertaan program KB.Tabel di atas menunjukkan bahwa dari 155 responden yang bersikap positif tentang alat kontrasepsi mayoritas ikut program KB sebanyak 138 orang $(53,1 \%)$. Dari 105 responden yang bersikap negatif tentang alat kontrasepsi mayoritas ikut program KB sebanyak 80 orang $(30,8 \%)$. Responden yang tidak ikut KB lebih banyak pada responden yang bersikap negatif sebanyak 25 orang $(9,6 \%)$.

Hasil uji statistik dengan menggunakan uji chisquare diperoleh $p$-value sebesar $0,009<0,05$ artinya terdapat pengaruh antara sikap terhadap keikutsertaan program KB.Tabel di atas menunjukkan bahwa dari 67 responden yang berperilaku baik mayoritas ikut program KB sebanyak 63 orang $(24,2 \%)$. Dari 164 responden yang berperilaku sedang mayoritas ikut program KB sebanyak 150 orang $(57,7 \%)$. Dari 29 responden yang berperilaku kurang baik mayoritas tidak ikut program KB sebanyak 24 orang $(9,2 \%)$. Responden yang tidak menggunakan alat kontrasepsi mayoritas pada responden yang berperilaku kurang sebanyak 24 orang $(9,2 \%)$. Hasil uji statistik dengan menggunakan uji chisquare diperoleh $p$-value sebesar $0,000<0,05$ artinya terdapat pengaruh antara perilaku terhadap keikutsertaan program KB.

\section{PEMBAHASAN}

Berdasarkan hasil penelitian menunjukkan bahwa ada pengaruh pengetahuan ibu terhadap keikutsertaan program KB di Kota Medan tahun 2019, $p=0,005<0,05$. Responden yang berpengetahuan baik mayoritas ikut program KB. Responden yang berpengetahuan sedang mayoritas ikut program KB $(35,8 \%)$. Responden yang berpengetahuan kurang mayoritas ikut program KB $(12,2 \%)$. Responden yang tidak menggunakan alat kontrasepsi lebih banyak pada responden yang berpengetahuan kurang.

Penelitian ini sejalan dengan penelitian sebelumnya di puskesmas Lolak Kabupaten Bolaang Mongondow dan di puskesmas Payung Rejo Kabupaten Lampung Tengah yang menunjukkan bahwa sebagian besar ibu memiliki pengetahuan cukup (52\%-60,7\%). Ada hubungan yang bermakna antara pengetahuan ibu dengan penggunaan Metode Kontrasepsi Efektif Terpilih. Alasan utama penggunaan IUD bagi responden adalah keamanan dari segi kesehatan dan 
Pengaruh perilaku ibu terhadap keikutsertaan program KB di kota medan tahun 2019

sebaliknya alasan responden menolak menggunakan IUD adalah perasaan tidak nyaman ketika proses pemasangan dan selama menggunakannya. Dapat disimpulkan bahwa pengetahuan responden disemua penelitian sebelumnya bahwa mereka sangat paham tentang penggunaan metode kontrasepsi (Rotie, 2015; Sari, 2016). Penelitian di Puskesmas Comoro Dili Timor Leste bahwa pengetahuan mempengaruhi perilaku seseorang, sehingga tingkat pengetahuan ibu terhadap KB berhubungan dengan perilaku ibu dalam berpartisipasi menggunakan metode kontrasepsi KB. Pengetahuan merupakan faktor dominan yang berhubungan dengan pemakaian alat kontrasepsi (Setyowati, 2010; Goncalves, 2014).

Faktor yang mempengaruhi pemilihan jenis kontrasepsi salah satunya adalah pengetahuan, faktor tersebut nantinya akan mempengaruhi keberhasilan program KB. Demikian juga beberapa teori yang menyatakan bahwa perilaku individu didasari oleh pengetahuan (kognitif), sikap (afektif), dan tindakan (psikomotorik) (Bloom, Krathwohl, \& Masia, 1984; Notoatmodjo, 2015). Beberapa teori menyatakan bahwa perilaku individu dipengaruhi oleh faktor predisposisi (predisposing factors), faktor pendukung (enabling factors), dan faktor penguat (reinforcing factors), dan salah satu dari faktor predisposisi adalah pengetahuan (Green, \& Kreuter, 1991; Notoatmodjo, 2015). Seseorang yang tidak mau menggunakan alat kontrasepsi dapat disebabkan karena orang tersebut tidak tahu atau belum mengetahui manfaat dari alat kontrasepsi bagi dirinya dan keluarganya (Fatimah, 2013; Affandi, 2014; Notoatmodjo, 2015).

Berdasarkan hasil penelitian ini membuktikan bahwa pengetahuan ibu berpengaruh terhadap keikutsertaan program Keluarga Berencana (KB). Responden yang menggunakan alat kontrasepsi lebih banyak pada ibu yang berpengetahuan baik, sedangkan yang tidak menggunakan alat kontrasepsi lebih banyak pada ibu yang berpengetahuan kurang. Pengetahuan yang dimaksud adalah pengetahuan ibu tentang penggunaan kontrasepsi terutama manfaatnya dalam mencegah kehamilan, efek samping alat kontrasepsi, dan lain-lain. lbu yang berpengetahuan baik akan muncul kesadaran dan niat untuk menggunakan alat kontrasepsi yang aman dan berkualitas, sesuai dengan kondisi tubuh ibu sehingga akan meminimalisir efek samping setelah melalui konseling dengan tenaga kesehatan. Keputusan penggunaan alat kontrasepsi yang didasari oleh pengetahuan akan bersifat langgeng (long lasting). Hasil penelitian ini juga menunjukkan bahwa ada pengaruh perilaku ibu terhadap keikutsertaan program KB dengan $p=0,000<0,05$. Responden yang berperilaku baik dan ikut program KB $(24,2 \%)$, yang berperilaku sedang dan ikut program KB $(57,7 \%)$, yang berperilaku kurang baik dan ikut program KB hanya $9,2 \%$, dan yang tidak menggunakan alat kontrasepsi mayoritas pada responden yang berperilaku kurang.

Penelitian yang dilakukan di Wilayah Kerja Puskesmas Purwosari Kota Surakarta didapatkan hasil bahwa perilaku lebih dari separuh responden mengikuti program KB yakni $72,5 \%$, sementara $27,5 \%$ perilaku responden tidak mengikuti program $\mathrm{KB}$, hasil bahwa terdapat pengaruh tindakan/perilaku terhadap Unmet Need KB (Nasrulloh, 2015). Seseorang yang telah mengetahui stimulus/objek kesehatan, kemudian mengadakan penilaian atau pendapat terhadap apa yang diketahui, proses selanjutnya diharapkan ia akan melaksanakan/mempraktikkan apa yang diketahui atau disikapinya (di nilai baik). Inilah yang disebut praktik (practice) kesehatan atau dapat dikatakan praktik kesehatan (overt behavior) (Agustini, 2014; Notoatmodjo, 2015).

Respon seseorang terhadap stimulus dalam bentuk tindakan nyata atau terbuka. Respons terhadap stimulus tersebut sudah jelas dalam bentuk tindakan atau praktik (practice), yang dengan mudah dapat diamati atau dilihat oleh orang lain. Oleh sebab itu disebut overt behavior, tindakan nyata/praktik (practice) (Wawan, \& Dewi, 2015). Perilaku seseorang atau masyarakat tentang kesehatan dipengaruhi oleh ketersediaan fasilitas kesehatan di lingkungan sekitarnya dan juga dipengaruhi oleh perilaku para petugas kesehatan dalam mendukung atau memberikan informasi kepada masyarakat (Hartanto, 2016).

Berdasarkan hasil penelitian ini membuktikan bahwa ibu dengan perilaku baik cenderung menjadi peserta program KB dan sebaliknya ibu dengan perilaku kurang cenderung tidak menjadi peserta KB. Perilaku ibu yang baik, disebabkan ibu memahami pentingnya menjadi akseptor KB dengan mencari informasi baik dari media maupun dengan bertanya kepada pihak yang berwewenang yaitu tenaga kesehatan. Keingintahuan ibu akan membawa ibu untuk mencari tahu apa itu kontrasepsi, jenis-jenis alat kontrasepsi yang ada di Indonesia, manfaat menjadi akseptor KB, keuntungan dan kerugian masing-masing alat 
Pengaruh perilaku ibu terhadap keikutsertaan program KB di kota medan tahun 2019

kontrasepsi, cara penggunaan masing-masing alat kontrasepsi, efek samping yang mungkin terjadi pada masing-masing alat kontrasepsi. Sedangkan ibu dengan tindakan kurang cenderung pasif, tidak ingin tahu tentang alat kontrasepsi yang dapat menjarangkan kehamilan/persalinan.

Setiap pasangan subur hendaknya mencari informasi tentang keluarga berencana (KB) dan jenis alat kontrasepsi yang cocok bagi dirinya. Tindakan atau perilaku tersebut perlu dimiliki oleh setiap PUS agar mampu mengendalikan kehamilan/kelahiran anak, ibu dan anak sehat, meningkatkan ketahanan keluarga, dan keluarga menjadi sejahtera sesuai dengan motto program keluarga berencana (KB) yakni dua anak lebih baik.

\section{SIMPULAN}

Dari hasil yang didapatkan pada penelitian ini bahwa pengetahuan ibu berpengaruh terhadap keikutsertaan program $K B, p=0,005$; sikap ibu berpengaruh terhadap keikutsertaan program $\mathrm{KB}$, $p=0,009$; dan perilaku ibu berpengaruh terhadap keikutsertaan program KB $p=0,000$.

\section{SARAN}

Kepada Pemerintah Kota Medan untuk lebih menggalakkan lagi program Keluarga Berencana (KB) terutama kepada anak-anak muda, karena saat ini banyak anak muda yang melakukan pernikahan dini yang melahirkan pada usia di bawah 20 tahun. Melalui kerjasama dengan BKKBN Kota Medan dalam melakukan promosi kesehatan tentang Keluarga Berencana, penggunaan alat kontrasepsi yang sesuai, pencegahan pernikahan usia dini.

Promosi kesehatan dengan penyuluhan atau pendidikan kesehatan dapat meningkatkan pengetahuan, merubah sikap yang negatif menjadi positif, dan meningkatkan tindakan menjadi lebih baik. Pada PUS yang tidak atau belum menggunakan alat kontrasepsi untuk menggunakan salah satu alat kontrasepsi yang tersedia, sehingga dapat menjarangkan kehamilan/kelahiran anak, menyehatkan ibu dan anak, serta peningkatan ketahanan dan derajat kesehatan keluarga menjadi keluarga sejahtera.

\section{DAFTAR PUSTAKA}

Affandi, B. (2014). Buku Panduan Praktis Pelayanan Kontrasepsi. Jakarta: Bina Pustaka Sarwono Prawirohardjo.

Agustini, A. (2014). Promosi Kesehatan. Deepublish.

Badan Kependudukan dan Keluarga Berencana Nasional. (2010). Survey Demografi Kesehatan Indonesia. Medan. BKKBN. Indonesia

Bloom, B. S., Krathwohl, D. R., \& Masia, B. B. (1984). Bloom taxonomy of educational objectives. In Allyn and Bacon. Pearson Education.

Dinas Kesehatan Provinsi Sumatera Utara. (2015). Profil Kesehatan Provinsi Sumatera Utara. Medan: Dinas Kesehatan Provinsi Sumatera Utara

Fatimah, D. (2013). Faktor-Faktor Yang Berhubungan Dengan Penggunaan Alat Kontrasepsi Dalam Rahim (AKDR) Di Wilayah Kerja Puskesmas Kecamatan Pasar Rebo.

Goncalves, M.J. (2014). Hubungan Pengetahuan dan Sikap dengan Pemakaian Alat Kontrasepsi pada PUS di Puskesmas Comoro Dili Timor Leste. Public Health and Preventive Medicine Archive. 2(1) : 52-58.

Green, L. W., \& Kreuter, M. W. (1991). Health promotion planning: an educational and environmental approach.

Hartanto, H. (2016). Keluarga Berencana Dan Kontrasepsi. Jakarta: Pustaka Sinar Harapan.

Kusumawati, I., Purwanti, P, \& Kusuma E, W. (2016). Hubungan Antara Motivasi Bidan Dengan Kepatuhan Pemberian Informed Consent Pada Pelayanan Keluarga Berencana (KB) Di Kecamatan Grogol (Doctoral dissertation, Universitas Muhammadiyah Surakarta 
Pengaruh perilaku ibu terhadap keikutsertaan program KB di kota medan tahun 2019

Nasrulloh, A. (2015). Hubungan Antara Pengetahuan, Sikap, Dan Dukungan Keluarga Dengan Keikutsertaan Pasangan Usia Subur (PUS) Dalam Ber-KB Di Wilayah Kerja Puskesmas Purwosari Kota Surakarta. Surakarta: Fakultas IImu Kesehatan Universitas Muhammadiyah Surakarta.

Notoatmodjo, S. (2015). Promosi Kesehatan Teori dan Aplikasi. Cetakan Kedua. Jakarta: Rineka Cipta.

Prawiroharjo, S (2008). IImu Kebidanan. Jakarta. Yayasan Bina Pustaka Sarwono Prawirohardjo

Rotie, N. (2015). Hubungan Pengetahuan dan Tingkat Pendidikan Ibu dengan Penggunaan Metode Kontrasepsi Efektif Terpilih. JIDAN. Jurnal IImiah Bidan. Januari - Juni 2015. 3(1) : 10-14.

Saifuddin, A. B. (2006). Buku panduan praktis pelayanan kontrasepsi. Jakarta: Yayasan Bina Pustaka Sarwono Prawirohardjo.
Sari, N. H. (2016). Hubungan pengetahuan ibu dengan penggunaan alat kontrasepsi iud di puskesmas payung rejo kabupaten lampung tengah.

Setyowati, T. (2010). Faktor-Faktor Yang Berhubungan Dengan Penggunaan Alat Kontrasepsi Dalam Rahim Pada Akseptor KB Golongan Resiko Tinggi Di Puskesmas Wilayah Kec. Cimahi Selatan Kota Cimahi Tahun 2008. J. Kesehatan. Stikes Kartika Ahmad Yani, 1-11.

Suratun, S. Heryani, \& Manurung, S. (2015). Pelayanan Keluarga Berencana dan Pelayanan Kontrasepsi. Jakarta: Trans Info Media.

Wawan, A., \& Dewi, M. (2015). Teori dan pengukuran pengetahuan, sikap dan perilaku manusia. Yogyakarta: Nuha Medika, 11-18. 